\title{
Communication Effect Research on the Anti-Racist Thought of African Americans
}

\author{
Shiyao Zhang1, a \\ ${ }^{1}$ History School, Liaoning University, Liaoning 110136, China; \\ ashiyaostudio@163.com
}

\begin{abstract}
Racism is one of the most important issues in American society, and the anti-racist movement has been a frequent one in the face of the injustices suffered by African Americans. As a major contributor to the development and implementation of antiracist movements, African Americans have taken a variety of effective measures to disseminate their thoughts and have achieved some success. However, the fact that the anti-racist movement in the US has often ended in dissipation reveals that there are still problems with the effect of the communication of thoughts, and it is important to explore these problems for the study of African Americans.
\end{abstract}

\section{Keywords}

African Americans, anti-racism, communication effect.

\section{Introduction}

Racism is a misconception that advocates the supposed superiority or inferiority of different races based on their physical and behavioural characteristics, which often leads to prejudice, discrimination, segregation and even violence against one or more races. ${ }^{[1]}$ Although most people have a clear understanding of racism, it is undeniable that racism still exists in different forms around the world. Historically, as a continuation of colonialism, racism in the United States has been regarded as one of its most important social and political issues, and the social status, legal rights and survival of African Americans has been a focal point of racial issues. ${ }^{[2]}$ Although race issues for African Americans were gradually resolved to some extent after American Civil War, the fact remains that oppression and disenfranchisement of African Americans persisted and was severe at certain times. At the same time, African Americans also carried out a number of anti-racist movements, in which anti-racist thoughts were disseminated to some extent and played a role, but did not achieve any substantial effect.The social status and survival of the black community in the United States, as well as the public policies implemented by the government towards them, have been discussed in detail, including Herbert J. Foster's study of African patterns in the AfricanAmerican family, ${ }^{[3]}$ Yogita Goyal's review of former slavery in the United States and Frederick D. Harper's study of Malcolm X, one of the leaders of African-American Civil Rights Movement, etc. ${ }^{[4]}$ It can be seen that the relevant discourse of these scholars mostly stays on the social and political level and less on the level of the communication of thoughts. ${ }^{[5]}$ However, while scholars have paid little attention to the communication of thoughts in the African American anti-racist movement, there are other social and political aspects of their work that are of great relevance to the discussion of communication. Social and political factors influenced the effect of the communication of anti-racist thoughts of African Americans, the means of communication, and the psychology of the audience, which in turn had a significant impact on the effect of communication. For example, Quintard Taylor's study of the shifting migrations of African American communities shows that the Internal differentiation that resulted from the suburbanization of the black middle class in America weakened the communication of anti- 
racist thoughts. ${ }^{[6]}$ Besides, as an example of a diplomatic history that has seen notable developments in recent years, the United States' diplomatic mishandling of racial issues (such as its withdrawal from the UN Human Rights Council) has also led to increased attention to the the African American anti-racist movement, both at home and abroad, which in turn has expanded the breadth of the communication of thoughts. ${ }^{[7]}$ This paper will synthesize and discuss the issues that have been discussed and not yet touched upon by academia, and will elaborate on the means and effects of communication used by African Americans in the antiracist movement and explore the relative lack of effect in the communication of thoughts in order to provide a new way of thinking about the race issue in America.

\section{Origins of the Anti-Racist Movement and Its Main Schools of Thought}

In American history, the voices of African Americans against racism can be traced back to the North American slave revolts that broke out in 1663 in Gloucester County, Virginia; similarly, in 1712, 1730 and 1739 in New York, South Carolina and Louisiana, but mostly ended in suppression. ${ }^{[8]}$ While the above revolts can be considered early organized anti-racist movements by African Americans, it was the American Civil War that was truly successful and achieved some results, a war that spurred such things as Emancipation Proclamation and Fourteenth Amendment to the United States Constitution, which gave African Americans certain rights. ${ }^{[9]}$ The same influence was also seen in the 1954-1968 civil rights movement, which also achieved certain results, such as the Civil Rights Act of 1964 and the Voting Rights Act of 1965, among others.

Early and influential anti-racist thoughts about African Americans can be traced back to the famous nineteenth-century thinker Frederick Douglass, whose ideas were very much a driving force in the abolitionist movement in the United States at the time and in the recreation of race relations during the reconstruction era from 1865 to $1877 .{ }^{[10]}$ His thoughts on identity have had an impact on the anti-racist movement to this day.

During the 1954-1968 civil rights movement in the United States, the African Americans involved at the time was divided between Martin Luther King Jr. and the Southern Christian Leadership Conference (SCLC), who advocated nonviolent action and integrationism. The other was the Black Power wave of the mid to late 1960s and its de facto spokesperson, Stokely Carmicheal, as well as the violent protest and secessionist Malcolm X and the Black Panther Party. ${ }^{[1]}$ Although they had some successes, they eventually came to an end for various reasons: the assassination of Martin Luther King and Malcolm X, the withdrawal of Stokely Carmichael from the political scene because he was not tolerated by the mainstream media and other factions, and the dissolution of the Black Panther Party in 1982 because its guiding ideology ran counter to the "anti-communist" ideology of the US government.

As the Black Power Movement in America continued to dissipate, the Black Arts Movement, sparked by the assassination of Malcolm X, began. Unlike the violent struggle advocated by Malcolm X, the Black Arts Movement focused more on the promotion of black identity, both internally and externally, and expanded the effectiveness of the dissemination of African American anti-racist thoughts from a literary perspective. ${ }^{[12]}$ The movement was influential in literature, history, film and television, music and painting, with the anti-racist literature and artworks of Imamu Amiri Baraka and his revolutionary pieces still having a profound impact today. ${ }^{[13]}$

\section{Ways and Effect of Anti-Racist Thought Communication}

In response to the persistence of racism in the United States, African Americans is constantly updating its communication methods and finding effective ways of communicating, with some success. The question of the effectiveness of the communication of anti-racist thoughts has benefited from the exploration of these avenues. 
Firstly, the increasing number and acceptance of African-American historiography, literature and film was a major factor in the successful spread of anti-racist thoughts. From the 1960s, when the assassination of the civil rights movement leader Malcolm X sparked the Black Arts Movement in the United States, African-American literature, historiography and film and television works have proliferated and flourished to this day. Toni Morrison, an African-American writer, wrote about the plight of African-American women in particular and won the Nobel Prize for Literature in 1993 for her work. ${ }^{[14]}$ African-American literature has also attracted White writers have also attracted white writers to pay attention to the current situation of African Americans' existence. Alice Goffman's book On the Run, published in 2014, described the living conditions and plight of the lower-class blacks in the United States at that time, and aroused widespread concern from all social strata, causing the public and relevant government officials to reflect on the irrationality of relevant public policies in the United States. ${ }^{[15]}$ In addition, the African American female historian and public intellectual Nell Irvin Painter and her masterpiece The History of White People, ${ }^{[16]}$ Ralph Ellison and his masterpiece Flying Home and Other Stories, ${ }^{[17]}$ and the African American woman director Ava DuVernay in her documentary 13th, to name but a few, have demonstrated an awareness of African Americans' condition on the literary, historical and artistic levels of film and television. ${ }^{\text {[18] }}$ These works and the social impact they had had a positive effect on the communication of anti-racist thoughts of African Americans.

Secondly, the use of prominent representatives of African Americans to spread anti-racist thoughts is also an important way of gaining public attention. Kareem Abdul-Jabbar, former star of the Los Angeles Lakers in the National Basketball Association, has long been involved in anti-racism activism and has spoken out against the injustices suffered by African Americans. Barack Hussein Obama, the 44th President of the United States, has also issued public statements saying that democracy in the United States does not work for African Americans. ${ }^{\text {[19] }}$ After the death of George Floyd in 2020, former Chicago Bulls star Michael Jordan of the National Basketball Association expressed his support for those who publicly denounced racial discrimination. ${ }^{[20]}$ These statements all provide a good political and social medium for the spread of anti-racist thoughts.

The press is one of the ways in which anti-racist thoughts is disseminated in the United States, and it is a medium that is more accessible to the public than other means of communication. In contrast to the previous distortion or even non-reporting of racial issues in the news media, in recent years, the news media's attention to related issues has become close to the norm. Taking the police brutality against African Americans in the United States from 2013 to 2017 as an example, six mainstream news media, CNN, NBC, Dallas Observer, Time, The New York Times and The Washington Post, reported a total of 194 similar cases. This led to a deeper awareness among the public of the injustice suffered by African Americans, which in turn led to the acceptance of the communication of anti-racist thoughts. Due to the padding of these objective reports, news media such as The Washington Post and USA Today provided timely coverage after the death of George Floyd in 2020. At the same time, the Japanese newspaper Asahi Shimbun, the Australian newspaper The Australian and the British newspaper The Guardian also spoke out on behalf of African Americans, thus leading other governments, international organisations and officials to successively condemn the blatant human right abuses committed by US law enforcement officers, the continued existence of systematic racial discrimination in US society in the 21st century, and the US government's "double standards" on human rights issues. This has had a very favourable impact on the communication of anti-racist thoughts. ${ }^{[21]}$

It is worth noting that African Americans has also sought to expand the influence of the anti-racist thoughts through its active participation in the social division of labour. This was reflected in the marked increase in the range of occupations held by the middle-class blacks. With the rise in political and economic status of African Americans since the mid-twentieth 
century, educational attainment has also improved significantly, leading to a wider range of career options and social status. ${ }^{[22]}$ Taking the percentage of African Americans among white collar employees in the United States as an example, the percentage of African Americans has been increasing continuously in the four years of 1950, 1960, 1970 and 1981, 9.76\%, 15.2\%, $23.85 \%$ and $40.60 \%$ respectively. ${ }^{[23]}$ This had a positive impact on the discourse of African Americans and the communication of anti-racist thoughts. Similarly, the participation of African Americans in external affairs also had the aforementioned impact. Take the Vietnam War, for example, in which there was a growing sense of resistance and racial consciousness among black soldiers against whites. This change is reflected in literatures, which depict the Vietnam War. This ideological climate was also carried over into the United States and had a beneficial effect on the communication of anti-racist thoughts at home. ${ }^{[24]}$

The anti-racist movement itself and the power of its communication have had a definite effect on American society and its people, as the campaign continues to grow and the channels of communication are constantly being updated. At the same time, there is a growing consensus among all sectors of American society to confront the problem of race in the United States and to address it in an appropriate manner. As the death of George Floyd in 2020 has gained increasing attention at home and abroad, with protests beginning in Minnesota and Texas, sweeping across all fifty states and spreading to hundreds of cities, including Washington DC, the capital of the United States. ${ }^{[25]}$ Not only African Americans, but also some whites and other minorities took to the streets for the legal rights of African Americans, and the slogan "Black Lives Matter" appeared frequently in the propaganda and news media in the United States and other countries. Gone with the Wind, a film adaptation of the novel of the same name, that played up slavery and glorified the slave-owning class in the South during the Civil War, was also boycotted by various classes in the US. The US film and television streaming platform HBO MAX has taken the film offline and has dismissed the film's depiction of racism and African Americans, stating that it will only be put back on the shelves after a critical commentary on this film. In an article in Los Angeles Times, renowned writer, producer and director John Ridley exposed the film's glorification of slavery and agreed with the fact that African Americans have been brutally oppressed throughout American history. ${ }^{[26]}$

One thing that needs to be recognized is that this massive protest movement and the secondary anti-racist movement that resulted from the death of George Floyd is the result of a long history of changes in social circumstances, popular psychology, world trends, and the efforts of various social groups. According to a poll released in Pew Research Center's Race in America 2019, 58\% of Americans surveyed (mostly whites and other minorities) believe that African Americans receive poor social treatment and legal rights and find it difficult to address them in the current system. ${ }^{[2]}$ This suggests that the American public has become more aware of This suggests that the American public has become more aware of and reflective of racial issues, and that the racist "agenda setting" has been largely broken. ${ }^{[28]}$ At the same time, the importance attached to human rights by countries around the world, as well as by relevant international organizations and the public, has forced the U.S. government to adjust its policy towards African Americans.On October 1, 2020, during the general debate on the topic of antiracism at the 45th session of the United Nations Human Rights Council, the United Nations High Commissioner for Human Rights, Michelle Bachelet, and representatives of various countries condemned racism and the Durban Declaration and Programme of Action should be intensively implemented by the international community. ${ }^{[29]}$ It is equally indicative of the increasing attention being paid to African-American anti-racist movements in the context of the development of the world human rights movement. 


\section{Analyses of the Factors Contributing to the Lack of Communication Effectiveness}

However, the racist movement was more active at certain times than the anti-racist movement of African Americans: the establishment of Ku Klux Klan, the erection of statues of southern generals, the enactment of Jim Crow laws, the Wilmington massacre of 1898 and the dismantling of different schools of thought in the civil rights movement, and the selective enforcement of laws by white American police. Examples include the Los Angeles riots of 1992 and George Floyd's death due to white police brutality.

By and large, there is still a huge gap between the social resources of African Americans and those of white, and the stereotypes of African Americans in the public perception have not been substantially improved, even the literature and art works that smear African Americans still have more influence. Why, then, has the anti-racist movements in the US often failed to make substantial progress? This has an important bearing on the communication effectiveness of African-American anti-racist thoughts. The following article intends to explore the factors contributing to the lack of communication effectiveness through the combing and analysis of African-American anti-racist thoughts, in order to provide some relatively effective directions for the effective communication of African-American anti-racist thoughts and the study of African Americans.

\subsection{Influence of Traditional Constitutional Thought and Judicial Compromise of Racism}

Back in 2017, when it came to the treatment of statues of former slave owners, Donald John Trump stated, "Are we gonna take down statues to George Washington?" It is a question to ponder, since the protesting groups want to reckon with the race issue, should they also tear down the statues of George Washington, who was the founding father of the United States, as well as the Father of the Constitution, Thomas Jefferson's statue ${ }^{[30]}$ They were both slave owners and founders of the American political system, and in the formation of the framework of the American political system and the creation of Constitution of 1787, democracy, freedom, and equality for all had already been inextricably linked to racism and slavery, and could not be separated, for example Constitution of 1787 provided that African Americans did not have the right to vote and that for the purpose of population enumeration, 1 black person was counted as 3/5 of a white person. ${ }^{[31]}$ With 233 years of constitutionalism, African Americans, in opposing racism and the former slave owners, must have been involved in the long-standing constitutional system and ideology of democracy, freedom and equality for all Americans based on Constitution of 1787, which was not easily accepted by all social classes and groups of people in the United States. This was not easy for all social classes and groups in the United States to accept, and was therefore an obstacle to the communication of the thought of a complete liquidation of slavery and racism.

Even after the adoption of the 14th Amendment to the United States Constitution, which guaranteed the rights of African Americans, the U.S. Supreme Court continued to adopt a relatively compromising attitude towards racist behaviour. For example, in the SlaughterHouse Cases (1873), Justice Miller artificially created the doctrine of "privileges and immunities" to distort the 14th Amendment to the United States Constitution. ${ }^{[32]}$ Similar problems arise in judicial practice such as United States v. Reese (1876), which the United States Supreme Court narrowly construed the 15th Amendment to the United States Constitution, created a significant impediment to the acquisition of basic citizenship rights by African Americans. ${ }^{[33]}$ This was followed in 1899 by the U.S. Supreme Court's adoption of the "separate but equal" notion in the Cumming v. Richmond County Board of Education decision, which created a juridical barrier to the communication of African-American anti-racist thoughts. ${ }^{[34]}$ 


\subsection{Historical Legacies and the Formation and Promotion of Related Organisations}

In the aftermath of the Civil War, the liquidation of the Confederacy was not complete, and with the assassination of Abraham Lincoln and the presidency of Andrew Johnson, a Southerner, President Johnson's incomplete implementation of his proclamation of amnesty, granting the enumerated non-pardoners the right to file "special petitions". The pardon of a large number of undeserving persons was marked by compromise, wavering and weakness towards the Southern insurgents. ${ }^{[35]}$ The appeasement of the South led the post-Civil War Southern states to deny political rights to African Americans beginning with the enactment of the Mississippi Black Codes (1866) and the "Southern History," racism through the formation of the Southern Historical Society (SHS) in New Orleans on May 1, 1869, the Association of the Army of Northern Virginia Veterans (AANVA) on November 3, 1870, and the Association of the Army of Northern Virginia (AANVA) in 1866. The Southern Historical Society (SHS), founded in New Orleans on 1 May 1869, the Association of the Army of Northern Virginia (AANVA), founded on 3 November 1870, and the "Ku Klux Klan", founded in 1866, and the "Confederate Veterans Association", founded in 1889, were the first organizations to be established. The United Confederate Veterans (UCV), founded in 1889, and the United Daughters of the Confederacy (UDC), founded in 1894, have written on history, politics, literature and art and education to whitewash the Civil War, racism and thus the "agenda setting" of communication science. ${ }^{[36]}$ Although some of these organisations have been disbanded or banned and the works banned by the federal government, the perceptions and racial attitudes formed within the United States have not dissipated to date, thus having many negative effects on the communication of anti-racist thoughts.

\subsection{Economic, Political and Propaganda Suppression}

The suppression of African Americans and individuals economically, politically, propagandistically and in terms of public opinion by white Americans can be both organised and unorganised. These repressive activities had a great impact on the economic status, political influence, and propaganda tools of African Americans. For example, in the Tulsa race massacre that took place in the Greenwood District in Tulsa between 31 May 1921 and 1 June 1921. ${ }^{[3]}$ The Greenwood district was razed by the genocide and arson that resulted from the conflict between "white supremacists" who were unhappy with the economic and social prosperity of African Americans and who suppressed it. However, at the time, an all-white jury blamed blacks and left whites alone, and under threat of racism, the Tulsa local archives and news reports were destroyed. ${ }^{[38]}$ In addition to this, the East St. Louis riots (1917), which were triggered by white racists using public opinion to blackmail African Americans into raping white girls, and the destruction of the black newspaper The Daily Record in Wilmington, by white groups in Wilmington in 1898 to undermine the successful election results of black political parties, as well as the Chicago riots (1968) and the Los Angeles riots (1992), among other events. ${ }^{[39]}$ It is worth noting that some racists have selectively destroyed parts of domestic archives and collections on African-American issues for the sake of public opinion, which has also created a number of disadvantages for the reasonable communication of antiracist thoughts by African Americans. ${ }^{[40]}$ The above-mentioned destruction of AfricanAmerican material possessions economically by some whites, the denial of their legal rights and personal security and political participation politically, and the destruction of the press and other media of propaganda and thus the loss of public opinion and discourse also weakened the power of the communication of African-American anti-racist thoughts, which was one of the important factors contributing to the lack of effectiveness of the communication.

\subsection{Limitation of Communication Intention and Effect by Literacy and Education Level}


There has been an inequitable distribution of resources for African-American culture and education in the United States. As a result of racial segregation and the 20th century movement to suburbanize the United States, African Americans continued to migrate to the central cities, creating "ghettos" as African-American settlement. The "ghetto" was not only an area of relative poverty, violence and decay, but also an area where resources were least allocated. ${ }^{[1]}$ The severe lack of educational resources and funding have led to the inadequacy and low quality of school buildings, support facilities, and teachers. In the 1960s, the Southern states often spent two to three times more on education for white students than for blacks, while the illiteracy rate for African Americans was six times higher than for whites. ${ }^{[42]}$ The backwardness of education has left African Americans without the quality of cultural education they deserve and without a cultural label similar to that of white Protestant culture and Asian Confucian culture beyond popular entertainment such as sports and popular music. Even where there is sufficient will to fight against racial discrimination and the values of racial equality, there is a lack of sufficient literacy to promote them. More importantly, the lack of not only economics, politics and education under the long period of segregation, but more importantly the segregation of African Americans from positive values, and the further loss of influence on favourable ways of behaviour and positive values for lower-class blacks after the suburbanisation of the middle-class blacks in the 1960s, made African Americans full of crime and violence, and the lack of conceptually correct understanding of anti-racist behaviour and the dissemination of ideas. This has reduced the legitimacy and legality of anti-racism for African Americans, and the behaviour of these lower-class blacks without the right values is in line with the long-held stereotype of African Americans, thus greatly reducing the effectiveness of the communication of anti-racist thoughts.

\subsection{Intra-Racial Polarisation Due to the Suburbanisation of Middle-Class Blacks}

As one of the important stage phenomena in 20th century America, suburbanisation also indirectly influenced the anti-racist power of African Americans. Due to the severity of urban problems and the accumulation of urban social problems, more and more people began to yearn for the beautiful scenery, comfortable living and spacious and quiet suburbs. ${ }^{[43]}$ Thus, middle-class white American increasingly moved to the suburbs. The interaction of the 'pull' of the suburbs and the 'push' of the cities, combined with the impact of the African-American civil rights movement in the 1950s and 1960s, greatly reduced the constraints on the free movement of African Americans, and in the 1970s, middle-class blacks moved in large numbers to the suburbs. In the 1970s, the black middle class moved in large numbers to the suburbs. The suburbanisation of middle-class blacks was on a dramatic rise in the 1970s and has maintained a marked increase in the following decades. According to the U.S. Census Bureau, in every subsequent U.S. census (decennial), a marked increase in the suburban African-American population is found, and by 2000, African Americans living in the suburbs already accounted for $39 \%$ of the total. ${ }^{[4]}$ The suburbanization of middle-class blacks not only separated the middle class from the lower class in geographic space, but also separated both in terms of culture and education, behaviour, and values, ${ }^{[45]}$ progressively developed a Protestant culture labelled the middle class, the lower class labelled by popular culture and hostility to society and the promotion of violence. ${ }^{[46]}$ The middle-class blacks, which is dominated by highly educated professionals, does not have significant conflicts with the white community in terms of behaviours and values, and is also better integrated into mainstream society, and is naturally generally not overly enthusiastic about anti-racist movements. This situation represents an excellent opportunity for American society to alleviate racial tensions and related social problems. However, it is worth mentioning that the suburbanisation of middle-class blacks have not only deprived lower-class of blacks of proper behaviour and values, but has also made the anti-racist movement of African Americans superficial due to the lack of necessary guidance from the middle class, and the anti-racist movement lacks a platform and remains only a disorganised act of violence. These issues have greatly reduced 
the legitimacy of the relevant anti-racist movements and the existence of African Americans, and have had a significant negative impact on the effectiveness of communication.

\subsection{Lack of Interaction with Other Immigrant Races}

African Americans has a low index of interaction compared to the level of interaction of other immigrant races.(as in Table 1)

Table 1 Interaction index between immigrant races, 1980-2010 (partial) ${ }^{[47]}$

\begin{tabular}{ccccc}
\hline & $\begin{array}{c}\text { Chicanos and } \\
\text { Non-Hispanic } \\
\text { Whites }\end{array}$ & $\begin{array}{c}\text { Chinese and Non- } \\
\text { Hispanic Whites }\end{array}$ & $\begin{array}{c}\text { Chicanos and } \\
\text { African Americans }\end{array}$ & $\begin{array}{c}\text { Chinese and African } \\
\text { Americans }\end{array}$ \\
\hline 1980 & 45.1 & 59.6 & 8.1 & 6.5 \\
2010 & 33.4 & 46.3 & 8.6 & 6.3 \\
\hline
\end{tabular}

In the United States, there are issues related to racial discrimination among immigrants other than African Americans, but in many cases African Americans lack the necessary interaction with these immigrants to form an effective synergy and to disseminate and support public opinion. The divisions within African Americans combined with the alienation of other immigrant races has led to 'the spiral of silence' for the relatively small number of black sympathisers, which has weakened communication. ${ }^{[48]}$ At the same time, there was a certain lack of communication and interaction between African Americans and other immigrant races, so that race riots resulting from the intensification of conflicts between blacks and whites could also endanger other immigrant races to some extent. In particular, immigrant races were greatly affected by the polarising tendency of African-American antiracist movements to ignore the law and social morality generated by the violent and socially hostile underclass subjects, such as the Los Angeles riots caused by white police brutality that left Asian restaurants, shops, etc. looted. ${ }^{[49]}$ This all led other immigrant races to question the legitimacy of African-American anti-racist movement to some extent, and had a significant negative impact on the effectiveness of the communication of anti-racist thoughts.

\section{Conclusion}

With the choice and use of communication channels by African Americans, AfricanAmerican anti-racist movements in the US have achieved remarkable results and gained some progress in recent years. More and more people, societies and political forces are paying attention to the rights and survival of African Americans. The influence of historical, literary, film and television works on the current situation of African Americans, as well as the influence of relevant media reports on the US government and the public, and the appeals of black elites, have all led to a continuous in-depth understanding and reflection on the current situation of African Americans. In addition, the influence of world human rights developments on the US government's public policy towards African Americans is also evident. However, we cannot ignore the fact that the current situation of African Americans and their legal rights are not sufficiently protected, and we must be fully aware of the favourable situation for the communication of anti-racist thoughts created by the social environment, the media, the psychology of the public, world trends and various social groups, and take advantage of it.

At the same time, it cannot be ignored that there are still considerable obstacles to the communication of anti-racist thoughts. Firstly, the constitutional character of the long history of the United States, in which freedom and slavery coexist,, has led to the contradiction of African-American opposition to and rejection of racism, and the lack of a conceptual base for the communication of thoughts. Secondly, the tendency towards unjust justice, the remnants of the Confederacy, the whitewashing of slavery and the Confederacy by white racial groups, 
the discrediting of African Americans and the inculcation of racism in education, created a conceptual resistance to blacks. At the same time, there was organised or unorganised white suppression of advanced African-American communities, looting of the developed AfricanAmerican economy, suppression of dominant African-American political parties and violence against influential African-American media. This left African-American propaganda without economic or political support and without a medium for dissemination. The quality and quantity of African-American anti-racist propaganda does not stand out in comparison to the quality of literary and artistic propaganda by white groups and Confederate residual organisations. The above-mentioned economic, political and propaganda repression of African Americans and the uneven distribution of social resources have left African Americans at a great disadvantage in terms of economic, political and cultural education levels, which, coupled with the lack of appropriate leadership in behavioural patterns and values, has left blacks with a great deficit in their propaganda power and willingness to propagate. Especially after the suburbanisation of middle-class blacks in the 1970s, the gap between the black middle class and the lower class grew wider due to the various levels mentioned above and the differences in values and behavioural influences. The integration of the middle class into mainstream culture and the commitment of the lower class to popular and violent culture, the lack of middle-class blacks anti-racist movement lacks a certain platform and leadership, and thus a major deficiency in propaganda, which is the result of the lack of education, cultural quality, values and behavioural styles of African Americans in question. In his speech, James D. Manning, an African-American archbishop of the United States, said that something was wrong within African Americans and that they did not understand the world. The division of values has led African-American movements to dwell on violence. At the same time, the lack of interaction with other minorities and the polarising trend of the African-American affirmative action movement added to the anti-racist propaganda. At the root of this, the historical perspective, the consideration of constitutional issues and the struggle for external power of African Americans as well as their own internal economic, cultural and educational, behavioural and value enhancement, and the reflection on the ways of anti-racist movement will be the factors that need to be urgently considered in the communication of anti-racist thoughts in America. At the same time, it is also important to consider how African Americans can make use of the existing conditions to take effective action in order to avoid factors that are detrimental to the effectiveness of anti-racist thoughts. All in all, the future of the antiracist movement in the US is bright, but it must also be acknowledged that the movement has a long way to go.

\section{References}

[1] Newman, D. M.: Sociology: exploring the architecture of everyday life (SAGE, Los Angeles 2012), p. 405.

[2] Takashi Fujitani; Geoffrey Miles White; Lisa Yoneyama: Perilous memories: the Asia-Pacific War (Duke University Press, North Carolina 2001), p. 303.

[3] Foster, H.: African Patterns in the Afro-American Family, Journal of Black Studies, Vol. 14 (1983) No. 2, pp. 201-232.

[4] Goyal, Y.: African Atrocity, American Humanity: Slavery and Its Transnational Afterlives, Research in African Literatures, Vol.45(2014)No.3, pp. 48-71; Harper, F.: The Influence of Malcolm X on Black Militancy, Journal of Black Studies, vol.1(1971)no.4, pp. 387-402.

[5] Sowell, T.: Ethnic america: a history (Basic Books, New York 1981).

[6] Taylor, Q.: The Great Migration: The Afro-American Communities of Seattle and Portland during the 1940s, Arizona and the West, Vol. 23(1981)No. 2, pp. 109-126.

[7] Information on: https://www.cnn.com/2018/06/19/politics/haley-pompeo-human-rightsbias/index.html 
[8] Irons, C.: Race and Liberty in the New Nation: Emancipation in Virginia from the Revolution to Nat Turner's Rebellion, The Journal of Southern History, Vol. 74(2008)No. 1, p. 162.

[9] Epstein, Lee: Walker, Thomas G.: Constitutional Law for a Changing America: Rights, Liberties, and Justice (CQ Press, Washington, D. C. 2007), p. 775.

[10] Andrews, W.: Frederick Douglass, Preacher, American Literature, Vol. 54(1982)No. 4, pp. 592-597.

[11] Schmidt, B. C.: Principle and prejudice: The Supreme Court and race in the progressive era. Part 3: Black disfranchisement from the KKK to the grandfather clause, Columbia Law Review, Vol.82(1982)No.5, pp. 835-905.

[12] Feuser, W.: Afro-American Literature and Negritude, Comparative Literature, Vol. 28(1976)No. 4, pp. 289-308.

[13] Information on: https://www.blackpast.org/african-american-history/black-arts-movement1965-1975/

[14] Davis, C., \& Morrison, T.: Interview with Toni Morrison, Presence africaine, Vol. 145(1988), pp. 141-150.

[15] Goffman, A.: On the run: Wanted men in a Philadelphia ghetto, American sociological review, Vol. 74(2009)No. 3, pp. 339-357.

[16] Gates, H. L.: \& Painter, N. I.: A Conversation With Nell Irvin Painter: On The History of White People, Du Bois Review: Social Science Research on Race, Vol. 7(2010)No.1, pp. 17-23.

[17] Becker, B. K.: Flying Home and Other Stories, MELUS, Vol.24(1999)No.2, p. 179.

[18] Johnson, C. C.: 13th, Journal of Pastoral Theology, Vol. 27(2017)No. 2, pp. 128-130.

[19] Esposito, L., \& Finley, L. L.: Barack Obama, Racial Progress, and the Future of Race Relations in the United States, Western Journal of Black Studies, Vol. 33(2009)No. 3.

[20] Carrington, B.: 'What I Said Was Racist-But I'm Not a Racist': Anti-Racism and the White Sports/Media Complex. In Sport and challenges to racism (Palgrave Macmillan, London 2011), pp. 83-99.

[21] Munoz, B.: Demonstrators, police must recognize journalist's roll in covering unrest, protests over George Floyd's killing, Gateway Journalism Review, Vol. 49(2020)No. 357, pp. 26-29.

[22] Thomas J.Durant, Jr., Joyce S.Louden.: The Black Middle Class in America:Historical and Contemporary Perspectives, The Atlanta University Review of Race and Culture, (1986)No. 4.

[23] Shi Qing-huan: Studies on the Composition and the Social Status of the American Black Middleclass in the 20th Century, Seeking Truth, (2012)No. 4, pp. 138-144. (In Chinese)

[24] Myers, K. A.: The paradoxes of anti-racist work: The impact of standpoint on strategy, Humanity \& Society, Vol. 25(2001)No. 2, pp. 131-152.

[25] Information on: https://www.nytimes.com/2021/04/20/us/george-floyd-chauvin-verdict.html [26] Bringing the Slave Narrative to Screen: Steve McQueen and John Ridley's Searing Depiction of America's "Peculiar Institution", Cinéaste, Vol. 39(2013)No. 1.

[27] Information on: https://www.pewsocialtrends.org/2019/04/09/race-in-america-2019/.April 9,2019 .

[28] McCombs, M. E., \& Shaw, D. L.: The agenda-setting function of mass media, Public opinion quarterly, Vol. 36(1972)No. 2, pp. 176-187.

[29] Information on: https://www.un.org/en/durbanreview2009/ddpa.shtml

[30] Information on: https://philadelphia.cbslocal.com/2017/08/15/trump-george-washingtonstatues/

[31] Tsesis, A.: The Inalienable Core of Citizenship: From Dred Scott to the Rehnquist Court,||, Arizona State Law Journal, Vol. 39(2008), p. 1179.

[32] Newsom, K. C.: Setting Incorporationism Straight: A Reinterpretation of the Slaughter-House Cases, The Yale Law Journal, Vol. 109(2000)No. 4, pp. 643-744.

[33] Information on: https://www.courtlistener.com/opinion/89266/united-states-v-reese/

[34] Connally, C. E.: Justice Harlan's “Great Betrayal”? A Reconsideration of Cumming v. Richmond County Board of Education, Journal of Supreme Court History, Vol. 25(2000)No. 1, pp. 72-92.

[35] Castel, Albert E.: The Presidency of Andrew Johnson. American Presidency. Lawrence (The Regents Press of Kansas, Kan 1979). 
[36] McCombs, M. E., \& Shaw, D. L.: The agenda-setting function of mass media, Public opinion quarterly, Vol. 36(1972)No. 2, pp. 176-187.

[37] Krehbiel, R.: Tulsa, 1921: Reporting a massacre (University of Oklahoma Press, Norman 2019).

[38] Information on: https://www.cnn.com/2020/06/01/us/tulsa-race-massacre-1921-99thanniversary-trnd/index.html

[39] Bergesen, A., \& Herman, M.: Immigration, race, and riot: The 1992 Los Angeles uprising, American Sociological Review, (1998), pp. 39-54.

[40] Marcus, C., \& Carlson, S.: Out of the Shadows: Bringing African American Digital Collections Together in Umbra Search African American History, Open Library of Humanities, Vol. 4(2018)No. 2.

[41] Haynes, B., \& Hutchison, R.: The ghetto: origins, history, discourse, City \& Community, Vol. 7(2008)No. 4, pp. 347-352.

[42] Aguirre Jr, A.: American ethnicity: The dynamics and consequences of discrimination, McGraw-Hill Higher Education Vol. 79(2011).

[43] Gainsborough, J. F.: Slow growth and urban sprawl: Support for a new regional agenda?, Urban Affairs Review, Vol. 37(2002)No. 5, pp. 728-744.

[44] Logan, J. R.: The new ethnic enclaves in America's suburbs. Report, Lewis Mumford Center for Comparative Urban and Regional Research (University of Albany, New York 2001).

[45] Fischer, M. J.: Shifting geographies: Examining the role of suburbanization in blacks' declining segregation, Urban Affairs Review, Vol. 43(2008)No. 4, pp. 475-496.

[46] Massey, D. S., \& Tannen, J.: Suburbanization and segregation in the United States: 1970-2010, Ethnic and racial studies, Vol. 41(2018)No. 9, pp. 1594-1611.

[47] Liang Maoxin: Qualitative Transformations of Ghettos in Post-war U. S. Cities, Studies of Modern World History, (2018)No. 1, pp. 3-29. (In Chinese)

[48] Noelle-Neumann, E.: The spiral of silence: a theory of public opinion, Journal of Communication, Vol. 24(1974), pp. 43-51.

[49] Bergesen, A., \& Herman, M.: Immigration, race, and riot: The 1992 Los Angeles uprising, American Sociological Review, (1998), pp. 39-54. 